\title{
ENVIRONMENTAL IMPACTS OF TRANSPORTATION TO THE POTENTIAL REPOSITORY AT YUCCA MOUNTAIN
}

\author{
R.L. Sweeney, USDOE Yucca Mountain Project; R. Best, Jason and Associates; \\ P. Bolton, P. Adams, Booz-Allen \& Hamilton Inc.
}

\begin{abstract}
The Environmental Impact Statement for a Geologic Repository for the Disposal of Spent Nuclear Fuel and High-Level Radioactive Waste at Yucca Mountain, Nye County, Nevada analyzes a Proposed Action to construct, operate, monitor, and eventually close a geologic repository for the disposal of spent nuclear fuel and high-level radioactive waste. As part of the Proposed Action, the EIS analyzes the potential impacts of transporting commercial and DOE spent nuclear fuel and high-lcvel radioactive waste to Yucca Mountain from 77 sites across the United States. The analysis includes information on the comparative impacts of transporting these materials by truck and rail and discusses the impacts of building a rail line or using heavyhaul trucks to move rail casks from a mainline railroad in Nevada to the site. This paper provides an overview of the analyses and the potential impacts of these transportation activities.
\end{abstract}

The potential transportation impacts were looked at from two perspectives: transportation of spent nuclear fuel and high-level radioactive waste by legal-weight truck or by rail on a national scale and impacts specific to Nevada from the transportation of these materials from the State borders to the Yucca Mountain site. In order to address the range of impacts that could result from the most likely modes, legal-weight truck and rail, the EIS employed two analytical scenarios - mostly legal-weight truck and mostly rail.

Estimated national transportation impacts were based on 24 years of transportation activities. Approximately 8 fatalities could occur from all causes in the nationwide general population from incident-free transportation activities of the mostly legal-weight truck scenario and about 4 from the mostly rail scenario.

The analysis examined the radiological consequences under the maximum foreseeable accident scenario and also overall accident risk. The overall accident risk over the 24 year period would be about 0.0002 latent cancer fatality for the mostly legal-weight truck scenario and about 0.0005 latent cancer fatality for the mostly rail scenario. The maximum reasonably foreseeable accident scenario resulted in 0.55 latent cancer fatality for the legal-weight truck case and 5 latent cancer fatalities in the case of mostly rail.

The EIS also analyzed the impacts associated with the transportation of spent nuclear fuel and high-level radioactive waste in the State of Nevada. This included:

- constructing a branch rail line and using it to ship waste to the repository

- upgrading highways in Nevada for use by heavy-haul trucks

- constructing and operating an intermodal transfer station

- transporting personnel and materials to support construction and operation of the repository 


\section{INTRODUCTION}

The Nuclear Waste Policy Act (NWPA) of 1982 established a comprehensive national program for the permanent disposal of spent nuclear fuel and high-level radioactive waste from commercial nuclear reactors and defense programs. In addition to tasking DOE with developing a repository for the disposal of these materials, the NWPA also requires DOE to provide for the transportation of the spent nuclear fuel and high-level radioactive waste from the storage locations to the repository. The NWPA, as amended in 1987, established a process leading to a decision by the Secretary of Energy on whether to recommend that the President approve Yucca Mountain in Nye County, Nevada for development of a geologic repository. Part of this process included preparation of an Environmental Impact Statement. A draft Environmental Impact Statement for a Geologic Repository for the Disposal of Spent Nuclear Fuel and High-Level Radioactive Waste at Yucca Mountain, Nye County, Nevada was published in July 1999. As part of the Proposed Action, the DEIS analyzed the potential impacts of transporting commercial and DOE spent nuclear fuel, including potential commercial spent mixed-oxide fuel, and high-level radioactive waste, including some that could contain immobilized surplus plutonium, to Yucca Mountain from 77 sites across the United States. Approximately 3500 comments were received on transportation. The Final EIS is available at www.ymp.gov. The transportation analyses in the FEIS were revised to respond to comments received on the DEIS and to reflect new information that had become available since publication of the DEIS.

This paper discusses the impacts of transporting spent nuclear fuel and high-level radioactive waste to the potential repository by rail and legal weight truck. It looks at the impacts from incident free transport as well as the impacts from accidents with each mode. In addition, it discusses in more detail, the impacts specific to transportation within the State of Nevada.

\section{IMPACTS OF NATIONAL TRANSPORTATION}

The EIS was prepared many years before shipments to a repository could begin. Therefore it was impossible to accurately predict the number of shipments that would be made by rail or truck. In order to ensure that the potential range of environmental impacts associated with the transportation of spent nuclear fuel and high-level radioactive waste was analyzed, DOE evaluated two scenarios for moving these materials to the potential repository:

- transport using mostly rail

- transport using mostly legal-weight truck

Under the mostly rail scenario, DOE would transport most of the spent nuclear fuel and highlevel radioactive waste by rail, with the exception of spent nuclear fuel from 6 commercial sites that do not have the capability to load rail shipping casks. Spent nuclear fuel from these sites would be shipped by legal weight truck. In addition, 24 commercial sites that have the capability to load rail casks but do not have rail access were assumed to ship their spent nuclear fuel by barge or heavy-haul truck to the nearest rail line. The Navy would ship its spent nuclear fuel from INEEL to the repository by rail also. Over the 24-year period used in the analysis there would be approximately 9600 rail shipments and 1100 truck shipments under this scenario. 
The mostly legal-weight truck scenario has most of the spent nuclear fuel and high-level radioactive waste being shipped to the potential repository by legal-weight truck. The one exception to this would be the shipment of Navy spent nuclear fuel by rail from INEEL to the repository. Over the 24-year period, this would amount to about 53,000 truck shipments and 300 rail shipments.

DOE expects that the mostly rail case, in which more than 95 percent of spent nuclear fuel and high-level radioactive waste would be shipped by rail, would most closely approximate the actual mix of truck and rail shipments. In reaching this conclusion, DOE has assessed the capabilities of the sites to handle rail casks, the distances to suitable railheads, and historical experience in actual shipments of nuclear fuel, waste, or large reactor-related components. In addition, DOE considered relevant information published by sources such as the Nuclear Energy Institute and the State of Nevada.

\section{Analytical Approach}

Three types of impacts to the public and workers could result from the transportation of spent nuclear fuel and high-level radioactive waste and other transportation activities associated with the repository construction and operation. The first of these analyzed in the EIS were radiological impacts, measured by radiological dose to populations and individuals and the resulting estimated number of latent cancer fatalities caused by radiation from shipments under normal and accident conditions. The second impact analyzed were the potential fatalities caused by vehicle emissions. Finally, the EIS looked at potential fatalities from vehicle accidents.

The analysis employed a database and widely accepted analytic tools, latest reasonably available information, and conservative but reasonable assumptions where there were uncertainties. The computer programs listed below were used in the analysis:

- CALVIN was used to estimate the number of shipments of spent nuclear fuel from commercial sites. For DOE spent nuclear fuel and high-level radioactive waste, the analysis used inventories and characteristics reported by DOE sites in 1998.

- HIGHWAY, using rules contained in U.S. Department of Transportation routing regulations, was used to select for analysis highway routes that are representative of ones that could be used to ship spent nuclear fuel and high-level radioactive waste from the 77 generator site locations.

- INTERLINE was used to identify representative rail and barge routes for the analysis.

- RADTRAN 5 in conjunction with the database was used to estimate radiological dose risk to populations and transportation workers during routine operations. The analysis also used this program and the database to estimate radiological dose risks to populations and transportation workers from accidents.

- RISKIND was used to estimate radiological doses to maximally exposed individuals from routine transportation and doses to populations and maximally exposed individuals from severe transportation accidents and acts of sabotage. 


\section{Number of Shipments}

As stated previously, DOE could not accurately predict the actual mix of rail and legal-weight truck shipments that would occur many years prior to the start of operations. Therefore the mostly rail and mostly legal weight truck scenarios were developed to bound the ranges of shipments that could occur over the 24 years of repository operations. Shown below is a summary of estimated numbers of shipments for the various inventory and national transportation analysis scenario combinations:

$$
\text { Truck } \frac{\text { Mostly Truck }}{\text { Rail }}
$$

Commercial Spent Nuclear Fuel

High-level radioactive waste

DOE and Navy spent nuclear fuel

TOTAL

$\begin{array}{rr}41,001 & 0 \\ 8,315 & 0 \\ 3,470 & 300 \\ 52,786 & 300\end{array}$

41,001

3,470

300

\author{
Mostly Rail \\ Truck Rail
}

1,079

7,218

1,663

765

9,646

\section{Incident-Free Transportation Impacts - Mostly Truck Scenario}

The EIS analyzed the radiological and non-radiological impacts to populations for the mostly truck scenario which also included 300 rail shipments of Navy spent fuel which were assumed to be moved to the repository using heavy haul trucks. Incident-free impacts could occur from exposure to external radiation in the vicinity of the transportation casks or vehicle emissions. RADTRAN 5, in conjunction with a database used to manage the large amounts of shipment, accident, and state-specific data, was used to estimate collective doses to the public residing within 0.5 miles of either side of the transportation route. In addition, the analysis also estimated doses to people who could be closer to shipments than the resident population along the route and to people who would be exposed for longer periods of time. Included in this group would be truck or rail crews, others working near the cask, people in vehicles sharing the route with the shipment, people at truck stops, and residents living near truck and rail stops.

The estimated radiological impacts would be 11.7 latent cancer fatalities for workers, including workers who would load shipping casks at generator facilities, and 2.5 latent cancer fatalities for the public over 24 years of operation. The potential impacts from increased levels of vehicle emissions could result in 0.95 fatalities.

The EIS also analyzed impacts to maximally exposed individuals, people who would receive the highest dose. The following were included in the analysis of national transportation impacts:

- Crew Members - truck and rail crews and security escorts

- Inspectors - Federal or state inspectors

- Railyard Crew Member

- Resident - person who lives 100 feet from a point where shipments pass and is exposed to all shipments along the route

- Individual Stuck in Traffic - person would be 4 feet from the transport vehicle for 1 hour 
- Resident Near a Rail Stop - assumes a person living 660 feet of a switchyard and is exposed for 20 hours to all rail shipments

- Truck Service Station Attendant - assumes individual would be exposed for 49 minutes, at a distance of 52 feet, to about $20 \%$ of all truck shipments - the fraction of shipments assumed to use the stop during the attendant's duty hours.

Inspectors and crewmembers would receive the highest radiation dose over 24 years.

In addition, the EIS analyzed impacts to maximally exposed individuals who could live or work near potential rail, heavy-haul truck, and legal-weight truck transportation routes in Nevada. These residents are assumed to be present at the nearest location in their residences or work places when each shipment passes during 24 years of operations. The following were included in the analysis:

- Resident living 15 meters from an intersection in North Las Vegas where heavy-haul trucks are postulated to stop for 1 minute during each trip and where traffic congestion would delay movement of a heavy-haul truck for a total of 30 minutes each year. The resident is assumed to be present when each shipment passes during a 10 year period while the North Las Vegas Beltway remains under construction.

- Resident who lives approximately 5 meters from U.S. 93 in Alamo, Nevada and who is assumed to be present when each heavy-haul truck shipment passes at a speed to 10 miles per hour.

- Worker at the courthouse or fire station in Goldfield, Nevada who could be as close as 5 meters to U.S. 95 and who is assumed to be present when each heavy-haul truck shipment passes at a speed of 5 miles per hour.

- Resident living 30 meters from a branch rail line in Nevada and who is assumed to be present when each rail cask shipment passes.

- A resident who lives 11 meters from a primary highway in southern Nevada and who is assumed to be present when each legal-weight truck shipments passes.

\section{Incident Free Transportation Impacts - Mostly Rail Scenario}

To estimate radiological and non-radiological impacts to populations for the mostly rail scenario, the analysis assumed all generator sites having the capability would load and ship spent nuclear fuel and high-level radioactive waste using rail casks. For those sites that are not served by a railroad, the analysis assumed that either heavy-haul trucks or barges would be used to move the rail casks to nearby railheads. About 24 sites would need to use barges or heavy-haul trucks; seven of these could only use heavy-haul trucks. The analysis includes impacts from legalweight truck shipments from the six commercial facilities that would not have the capability to load rail casks. In addition, since there is currently no rail access to the repository, this analysis assumed that DOE would either build a branch rail line or use heavy-haul trucks in Nevada to move the casks from the main line railroad to the repository. Therefore the results of the analysis indicate a range of impacts depending on the alternative selected. 
The estimated radiological impacts would be 1.5-1.9 latent cancer fatalities for workers and 0.6 0.8 latent cancer fatalities for the public over 24 years of operation. The potential impacts from increased levels of vehicle emissions could result in less than $1(0.6$ to 0.8$)$ fatalities.

In the analysis of maximally exposed individuals, truck and rail crew members, along with escorts traveling with rail shipments, would receive the highest dose over 24 years.

\section{Transportation Accident Scenarios}

Three types of accidents could occur during the transportation of spent nuclear fuel and highlevel radioactive waste to a repository: (1) accidents in which the damage to a cask would not affect its safety functions, (2) accidents that release radioactive materials, but in which there is no loss of shielding, and (3) accidents that release radioactive material and where a fraction of the cask's radiation shielding is lost. The Nuclear Regulatory Commission estimates that in 99.99 percent of rail and truck accidents no cask contents would be released and the primary gamma shielding would remain in place. The EIS also estimated the impacts from an unlikely but severe accident scenario called a maximum reasonably foreseeable accident. The accident analysis evaluated radiological impacts to populations and to hypothetical maximally exposed individuals and estimated fatalities that could occur from traffic accidents.

\section{Accident Impacts - Mostly Truck Scenario}

This analysis included impacts and risks associated with legal-weight truck shipments and Navy rail shipments plus the heavy-haul of the rail shipments in Nevada. Total number of accidents in this scenario would be 66 over the 24 -year period of operation. The radiological accident dose risk, which is the product of the population dose from potential accidents and the probability of the accidents occurring, would be 0.5 person-rem for the population within 50 miles along the transportation routes. This is equivalent to a 0.02 percent $(0.0002)$ risk of one latent cancer fatality in a population of more than 10 million.

The maximum reasonably foreseeable truck accident, which is an accident having the greatest consequences whose frequency of occurring would be greater than once in 10 million years, would be a long duration severe fire that fully engulfed a cask. The analysis estimated this truck accident could cause a population dose of about 1,080 person-rem, which is equivalent to 0.55 latent cancer fatality. In this accident, the analysis estimated that a maximally exposed individual member of the general public would receive a dose of about $3 \mathrm{rem}$. The analysis also estimated the maximum consequences of the crash of a commercial airliner into a legal-weight truck cask. Estimated impacts of this hypothetical accident $-1,140$ person-rem $(0.57$ latent cancer fatalities) were nearly the same as those for the maximum reasonably foreseeable accident.

Approximately 5 traffic fatalities would result over the 24 -year operating period. These would all be from truck shipments; none would be attributed to the 300 Navy rail shipments. 


\section{Accident Impacts - Mostly Rail Scenario}

The analysis of accidents in this scenario included accidents that would involve the truck shipments for the six reactors that cannot handle a rail cask. The analysis of the mostly rail scenario estimated that about 10 accidents would occur over the 24 years of operation. The collective radiological accident dose risk (dose risk is the sum of the products of the dose consequences of accidents and probabilities the accidents would occur) would be approximately 1 (0.89) person-rem for the population within 50 miles along transportation routes. This dose risk is equivalent to a 0.05 percent $(0.0005)$ increase in the risk of one additional latent cancer fatality in the population within 50 miles of the routes used. In this scenario rail transportation would account for most of the accident risk to the public.

The maximum reasonably foreseeable rail accident, which is an accident having the greatest consequences whose frequency of occurring would be greater than once in 10 million years, would be a long duration severe fire that fully engulfed a cask. The analysis estimated this rail accident could cause a population dose of about 9,900 person-rem, which is equivalent to 5 latent cancer fatalities. In this accident, the analysis estimated that a maximally exposed individual member of the general public would receive a dose of about $29 \mathrm{rem}$. The analysis also estimated the maximum consequences of the crash of a commercial airliner into a rail cask. Estimated impacts of this hypothetical accident - 1,350 person-rem ( 0.7 latent cancer fatalities) are less than those for the maximum reasonably foreseeable accident.

Under this scenario, there could be 3 traffic fatalities over 24 years, essentially all involving train operations.

\section{Impacts from Acts of Sabotage}

The EIS considered the impacts of a successful attack on a cask with the attack postulated to occur in the center of a highly populated metropolitan area. The analysis used data from a study of the effects of high-energy-density devices directed against casks containing spent nuclear fuel conducted by Sandia National Laboratories. DOE had Sandia do the study because of comments provided by the state of Nevada and others. The Sandia study estimated releases of radioactive materials under conditions where the action of a high-energy-density device was assumed to be optimally directed against a cask's shield wall. The analysis evaluated consequences for events involving both a truck cask and a rail cask.

The analysis estimated that an attack on a truck cask in an urban area could result in a maximally exposed individual receiving a lifetime-committed dose of $110 \mathrm{rem}$. This would increase the risk of a fatal cancer for the individual from about 23 percent from all other causes to about 29 percent.

The impacts from an attack on a rail cask would be less than those estimated from a truck cask because less material would be released. A maximally exposed individual in this case could receive a lifetime-committed dose of 40 rem which could increase the risk of a fatal cancer from about 23 percent form all other causes to about 25 percent. 


\section{IMPACTS OF TRANSPORTATION IN NEVADA}

Spent nuclear fuel and high-level radioactive waste entering Nevada on legal-weight trucks would continue on to the repository on those trucks. There currently is no rail line to the potential repository site; therefore, material traveling to Nevada by rail would travel to the repository on a newly built branch line or, if no line was constructed, move by heavy-haul truck. For this reason, the EIS evaluated three scenarios in Nevada: (1) mostly legal-weight truck, (2) mostly rail, and (3) mostly heavy haul.

\section{Legal-Weight Truck Scenario}

The impacts from the mostly legal weight truck, which includes heavy haul of rail casks containing Navy spent nuclcar fuel to the site, would correspond to the Nevada portion of the national impacts for the mostly legal weight truck scenario. Incident free impacts would be 0.75 latent cancer fatalities to workers and 0.18 latent cancer fatalities to the public. Crewmembers and inspectors would be the maximally exposed individuals. There would be about a 9 percent $(0.09)$ chance of one fatality in Nevada from exposure to transport vehicle emissions over the 24year operational period.

The radiological impacts from accidents would be 0.00003 latent cancer fatality to the exposed population within 50 miles of the routes. The results of a maximum reasonably foreseeable accident would be the same as that calculated for the national transportation scenario although the frequency for this accident to occur in Nevada would be less than once in 10 million years.

\section{Impacts of the Nevada Rail Implementing Alternatives}

For this scenario, DOE evaluated the impacts of building a branch line and operating trains for each of five candidate corridors. The corridors range in length from 159 to 520 kilometers (98 to 320 miles). In addition to estimating health and safety impacts, DOE assessed impacts that could occur in eleven other environmental resource areas for construction and operation of a branch rail line from a main line railroad to the Yucca Mountain site. The EIS presents DOE's analysis of impacts to land use; air quality; surface water and groundwater resources; biology and soils; cultural resources; socioeconomics; aesthetics; noise; waste management; utilities, energy, and materials; and environmental justice concerns. The analysis found that construction and use of a branch rail line in each of the candidate corridors would have unique impacts. Notable among these unique impacts are that corridors:

- cross or incur into the Air Force's Nellis Tèst and Training Range,

- cross wilderness study areas,

- conflict with lands set aside by acts of Congress, including the Timbisha Shoshone trust lands near Scotty's Junction, Nevada and the Ivanpah Valley Airport lands near Jean, Nevada,

- corridors cross desert tortoise habitat and approach habitat for other threatened and endangered species,

- cross areas having cultural resources such as the Pony Express Trail,

- cross potential flood areas and wetlands, 
- require use of water for construction in areas where use of groundwater resources has been fully allocated,

- cross land areas BLM has designated as having valuable (Class II) visual resources whose disturbance should be limited,

- cross land areas where the current natural setting is valued as part of the recreation experiences, and

- introduce construction and train noise into areas where preservation of natural background sound may be valued and a part of the cultural heritage of Native American Indians in the region.

DOE concluded that impacts to regional socioeconomics; waste management; and utilities, energy, and materials would be small for all of the counties in the region of influence. It also concluded that construction and use of a branch rail line in any of the corridors would not lead to impacts to environmental justice concerns.

Incident-free health and safety transportation impacts to people who lived along candidate rail corridors would be unique for each corridor although the impacts to maximally exposed individuals would be similar for each corridor with shipment inspectors receiving the highest exposure. DOE anticipates that a radiation protection program would be implemented for inspectors who would have the potential to receive such doses.

Under the national mostly rail scenario, the radiological impacts to populations in Nevada from transporting spent nuclear fuel and high-level radioactive waste from the borders of the State and ultimately on a branch rail line would be small, ranging from 19 person-rem to 130 person-rem ( 0.009 to 0.06 chance of a latent cancer fatality in the exposed population) over the 24 years of operations.

Accivent nsks woulci be neariy the same for all potenuai corriciors. Estimated impacts irom potential accidents ranged from 0.0000009 to 0.000004 latent cancer fatalities over the 24-year period.

\section{Impacts of the Nevada Heavy-Haul Alternatives}

This scenario evaluates the impacts of building and operating an intermodal transfer station and upgrading associated highways for use by heavy-haul trucks. Three potential station sites and five-associated highway routes were examined. The routes range in length from 183 to 533 kilometers (114 to 331 miles). In addition to estimating health and safety impacts, DOE assessed impacts that could occur in eleven other environmental resource areas. The impacts were assessed for upgrading highways and constructing and operating an intermodal transfer station located along a main line railroad and operating heavy-haul trucks to transport rail casks to the Yucca Mountain site. The EIS presents DOE's analysis of impacts to land use; air quality; surface water and groundwater resources; biology and soils; cultural resources; socioeconomics; aesthetics; noise; waste management; utilities, energy, and materials; and environmental justice concerns. The analysis found that upgrading highways, constructing and operating an intermodal transfer station, and operating heavy-haul trucks would have unique impacts. Notable among these unique impacts are: 
- one route would cross the Air Force's Nellis Test and Training Range,

- routes would cross desert tortoise habitat and approach habitat for other threatened and endangered species,

- routes would cross or pass near potential flood areas and wetlands,

- upgrading highways would require use of water in areas where use of groundwater resources has been fully allocated, and

- heavy-haul trucks would interfere with free flow of traffic on Nevada highways that would be used

DOE concluded that impacts to regional socioeconomics; waste management; and utilities, energy, and materials would be small for all of the counties in the region of influence. It also concluded that upgrading highways and constructing and using an intermodal transfer station and operating heavy-haul trucks would not lead to impacts to environmental justice concerns.

Personnel working at the intermodal transfer would be exposed to radiation from the shipping casks being transferred from rail cars to heavy haul trucks. It is estimated that there would be an 11 percent chance $(0.11)$ of one latent cancer fatality among the worker population at an intermodal transfer station from exposures incurred over the 24-year operating period.

Incident free transportation impacts to workers and people who lived along routes would be unique for each of the implementing alternatives. Estimated impacts to a maximally exposed individual, which in this case would be a crewmember, would be the same for all alternatives. DOE anticipates that radiation exposure of heavy-haul vehicle crews would be managed under a radiation protection program with exposures maintained as low as reasonably achievable.

Under the national mostly rail scenario, the radiological impacts to populations in Nevada from transporting spent nuclear fuel and high-level radioactive waste from the borders of the State to an intermodal transfer station and ultimately by heavy-haul trucks would be small, ranging from 61 person-rem to 300 person-rem ( 0.03 to 0.15 chance of a latent cancer fatality in the exposed population) over the 24 years of operations.

Accident risks would be nearly the same for all potential alternatives. The estimated impacts would range from 0.000001 to 0.00006 latent cancer fatality.

\section{SUMMARY}

DOE believes that the EIS provides the environmental impact information necessary to make certain broad transportation-related decisions, namely the choice of a national mode of transportation, the choice among alternative transportation modes in Nevada, and the choice among alternative rail corridors or heavy-haul truck routes and intermodal transfer stations. DOE has identified mostly rail as its preferred mode, both nationally and in Nevada. However, the Department has not identified a preference among the potential rail corridors at this time.

If the potential repository site is approved, transportation will move to the forefront as a major part of the waste management program. DOE is committed to complying with all applicable 
WM'02 Conference, February 24-28, 2002, Tucson, AZ

Federal, state, tribal, and local regulations concerning transportation and believes that the excellent safety record of spent fuel shipments over the past 30 years will continue. 